\title{
ANALISIS POTENSI OBJEK WISATA TAMAN REKREASI MUKO-MUKO DI KECAMATAN TANJUNG RAYA KABUPATEN AGAM
}

\author{
Armansyah', Rahmanelli², dan Dedi Hermon² \\ Program Studi Pendidikan Geografi \\ Fakultas Ilmu Sosial, Universitas Negeri Padang \\ Email : grbramansyah@gmail.com
}

\begin{abstract}
ABSTRAK
Penelitian ini bertujuan untuk mendeskripsikan data potensi objek wisata Taman rekreasi Muko-Muko di Kabupaten Agam, meliputi analisi potensi objek wisata (daya tarik, aksesibilitas, dan prasarana), persepsi pengunjung, partisipasi masyarakat yang beraktivitas ekonomi di Taman Muko-Muko. Jenis penelitian ini adalah penelitian dengan pendekatan kuantitatif, menggunakan data primer dan data sekunder. Teknik analisis data yang di gunkan adalah teknik analisis skoring dengan menggunakan kelas interval dan analisis TOWS
\end{abstract}

Kata Kunci: Potensi, Objek Wisata

\section{ABSTRACT}

This study aims to describe the potential data of tourism objects in Muko-Muko Recreational Park in Agam regency, including analysis of potential tourist objects (attraction, accessibility, and infrastructure), visitor perceptions, community participation in economic activities in Muko-Muko Park. This type of research is a quantitative approach research, using primary data and secondary data. Data analysis techniques used are scoring analysis techniques using class intervals and TOWS analysis.

Keywords: Potential, Tourist Attraction

\section{PENDAHULUAN}

Pariwisata pada umumnya
sering digunkan dalam istilah
"Pengunjung atau visitor". Visitor
adalah setiap orang atau kelompok
orang yang datang ke suatu daerah
atau negara lain dengan maksud
apapun kecuali untuk menerima upah
(Bakarudin, 2009)
Taman Muko-Muko
merupakan salah satu taman rekreasi terbesar di Kabupaten Agam dengan luas lebih kurang $4 \mathrm{Ha}$ terletak di Nagari Koto Malintang, Kecamatan Tanjung Raya, Kabupaten Agam sekitar 45 km dari Kota Bukittinggi,
$15 \mathrm{~km}$ Lubuk Basung dan $120 \mathrm{~km}$ dari Kota Padang. Pengunjung objek wisata ini tidak hanya dari wisatawan lokal namun juga wisatawan mancanegara dari data kunjungan wisatawan Tahun 2016 kunjungan wisatawan lokal 95.568 orang dan wisatawan mancanegara 6.483 orang (Dinas Pariwisata Kabupaten Agam).

Objek wisata Taman MukoMuko menerapkan sistem pembayaran karcis bagi pengunjung yang masuk. Karcis masuk berwarna Merah dan karcis parkir kendaraan berwarna hijau. Harga masing-masing karcis bervariasi untuk karcis masuk

\footnotetext{
${ }^{1}$ Mahasiswa Program Studi Pendidikan Geografi

2 Dosen Jurusan Geografi Fakultas Ilmu Sosial Universitas Negeri Padang
} 
terdiri dari dua tipe karcis yaitu karcis dewasa dan anak-anak. Adapun untuk karcis dewasa bertarif Rp. 4.000,sedangkan untuk karcis anak-anak Rp. 2.000,-. Beda halnya dengan karcis parkir, terdiri dari 3 tipe yaitu roda dua, roda empat dan roda enam. Untuk roda dua bertarif Rp. 2.000,roda empat Rp.3.000,- dan roda enam Rp 5.000,- (Peneliti, 2018).

Menurut Suwantoro (2004)

Daya tarik wisata yang juga disebut objek wisata merupakan potensi yang menjadi dorongan kehadiran wisatawan ke suatu daerah tujuan wisata. Prasana wisata adalah sumber daya alam mutlak dibutuhkan oleh wisatawan dalam perjalanannya di daerah tujuan wisata, seperti jalan, listrik, air, telekomunikasi, terminal, jembatan dan lain sebagainnya. Pembangunanan prasarana wisata mempertimbangkan kondisi dan lokasi akan meningkatkan aksesibilitas suatu objek wisata yang pada gilirannya akan meningkatkan daya tarik objek wisata itu sendiri. Kebutuhan wisatawan lainnya yang perlu tersedia di daerah objek wisata seperti ATM / Bank, Apotek, Puskesmas/ Rumah Sakit, SPBU, pusat-pusat perbelanjaan dan sebagainnya.

Penelitian ini akan menganalisis potensi objek wisata dengan menilai daya tarik, aksesibilitas, ketersedia prasarana pokok dan pelengkap dengan adanya ketersedia dan kelengkapan fasilitas akan menunjang kepuasan wisatawan pada objek wisata Taman MukoMuko.

Penelitian ini akan menganalisis potensi dengan analisis TOWS diharapkankan dapat di pertimbangkan untuk pengembangan objek wisata Taman Muko-Muko kedepannya agar meningkatkan pendapatan masyarakat yang beraktivitas ekonomi dan juga pendapatan daerah.

\section{METODE PENELITIAN}

Jenis penelitian yang digunakan dalam penelitian ini adalah deskriptif dengan pendekatan kuantitatif dimana menurut Sudjana (2004) yakni mengungkapkan masalah yang terjadi pada masa sekarang sebagaimana adanya berdasarkan perhitungan atau angka.

Penelitian deskriptif lebih mengarah pada pengungkapan suatu masalah atau keadaan sebagaimana adanya dan mengungkapkan faktafakta yang ada, walaupun kadangkadang diberikan interprestasi atau analisis, sedangkan penelitian kuantitatif merupakan penelitian yang informasinya atau data-datanya dikelola dengan tabel statistik (Tika, 2005). Sedangkan menurut Arikunto (2006) bahwa penelitian deskriptif tidak dimaksudkan untuk menguji hipotesis tertentu, tetapi hanya menggambarkan apa adanya tentang variabel, gejala atau kejadian.

Penelitin ini dilakukan selama 2 bulan, yaitu pada bulan Januari - 
Februari 2018. Tempat penelitian dilakukan di Objek Wisata Taman Muko-Muko, Kecamatan Tanjung Raya, Kabupaten Agam.

Arikunto (2006) menyatakan bahwa populasi adalah keseluruhan subjek penelitian. Dalam penelitian ini populasi yang di gunakan yaitu seluruh pengunjung yang datang ke Obyek Wisata Taman Rekreasi Muko-Muko di Kabupaten Agam.

Dalam menentukan besarnya jumlah sampel yang diperlukan untuk mewakili suatu populasi, menurut Tika (2005) mengatakan bahawa "Sampai saat ini belum ada ketentuan yang jelas tentang batas minimal besar sampel yang dapat diambil san mewakili suatu populasi yang akan diteliti, demikian dengan teori sampling dikatakan bahwa sampel terkecil dan dapat mewakili distribusi normal adalah 30 ".

Sampel adalah bagian dari jumlah dan karakteristik yang dimiliki oleh populasi tersebut (Sugiyono, 2011). Dengan demikian sampel adalah sebagian dari populasi yang karakteristiknya hendak diselidiki, dan bisa mewakili keseluruhan populasinya sehingga jumlahnya lebih sedikit dari populasi.

Jumlah Populasi dalam penelitian ini adalah seluruh wisatawan yang berkunjung ke objek wisata Taman Muko-Muko yang berjumlah 95.568 wisatawan lokal dan 6.483 Mancanegara. Dalam penelitian ini penulis mempersempit populasi yaitu jumlah keseluruhan
Pengunjung 103.051 wisatawan dengan menghitung ukuran sampel yang dilakukan dengan menggunakan teknik Slovin menurut Sugiyono (2011). Adapun penelitian ini menggunakan rumus Slovin karena dalam penarikan sampel, jumlahnya harus representative agar hasil penelitian dapat digeneralisasikan dan perhitungannya pun tidak memerlukan tabel jumlah sampel, namun dapat dilakukan dengan rumus dan perhitungan sederhana.

Rumus Slovin untuk menentukan sampel adalah sebagai berikut :

Keterangan:

$$
n=\frac{N}{1+N(e)^{2}}
$$
$\mathrm{n}=$
Ukuran sampel/jumlah
responden
$\mathrm{N}=$ Ukuran populasi
$\mathrm{E}=$ Persentase kelonggaran ketelitian kesalahan pengambilan sampel yang masih bisa ditoleransi; $\mathrm{e}=$ 0,2

Dalam rumus Slovin ada ketentuan sebagai berikut:

Nilai e $=0,1(10 \%)$ untuk populasi dalam jumlah besar

Nilai e $=0,2(20 \%)$ untuk populasi dalam jumlah kecil

Jadi rentang sampel yang dapat diambil dari teknik Solvin adalah antara 10-20\% dari populasi penelitian. Jumlah populasi dalam penelitian ini adalah sebanyak 
103.051 wisatawan, sehingga presentase kelonggaran yang digunakan adalah $20 \%$ dan hasil perhitungan dapat dibulatkan untuk mencapai kesesuaian. Maka untuk mengetahui sampel penelitian, dengan perhitungan sebagai berikut:

Rumus Slovin:

$$
\begin{gathered}
n=\frac{N}{1+N(e)^{2}} \\
n=\frac{103.051}{1+103.051(0.2)^{2}} \\
=25,1 ; \text { disesuaikan oleh peneliti }
\end{gathered}
$$

menjadi 30 responden untuk pengunjung $=29,5 ;$ Disesuaikan oleh peneliti menjadi 30 responden untuk

\begin{tabular}{|c|c|c|c|}
\hline No & Jenis Populasi & $\begin{array}{c}\text { Sampel } \\
\text { yang } \\
\text { diambil }\end{array}$ & Instrumen \\
\hline 1 & Pengunjung & 30 & Kuesioner \\
\hline 2 & $\begin{array}{l}\text { Masyarakat } \\
\text { Yang } \\
\text { beraktivitas } \\
\text { Ekonomi } \\
\text { dikawasan } \\
\text { wisata }\end{array}$ & 10 & Kuesioner \\
\hline & Total & 40 & \\
\hline
\end{tabular}
pengunjung

Tabel 1. Populasi dan sampel Penelitian

Sumber: Pengolahan Data Primer, 2018

Data yang digunakan dalam penelitian ini bersumber dari data primer dan data sekunder. Menurut Sugiyono (2011), sumber primer adalah sumber data yang langsung memberikan data kepada pengumpul data, sedangkan sumber sekunder merupakan Sumber yang tidak langsung memberikan data kepada pengumpul data, minsalnya lewat orang lain atau dokumentasi.
Sumber data yang di perlukan dalam penelitian ini untuk mencapai tujuan penelitian yang telah ditetapkan, data primer di dapat dari responden yaitu pengunjung dan masyarakat yang beraktivtas ekonomi objek wisata Taman Rekreasi Mukomoko pada saat penelitian dilakukan, data sekunder diperoleh dari instansi terkait seperti BAPPEDA, BPS, Dinas Pariwisata dan data statistik lainnya serta studi kepustakaan.

\section{Data primer dikumpulkan} dengan menggunakan daftar pertanyaan yaitu Instrumen penelitian atau yang dimaksud di sini yaitu penyebaran angket atau kuesioner secara Accidental sampling tentang Taman Muko-Muko ini dan juga dokumentasi kawasan obyek wisata Taman Muko-Muko, sedangkan data sekunder di peroleh melalui pencatatan sesuai dengan data yang di butuhkan dalam penelitian. Data sekunder yang dibutuhkan peneliti meliputi UU, Peraturan Pemerintah, RTRW, Peta Administrasi Kabupaten Agam, dan data kunjungan wisatawan.

Alat pengumpul data dalam penelitian ini berupa pencatatan hasil sebar kuesioner (informan), Pengamatan (cek lapangan/ Observasi) dan dokumentasi. Pengumpulan data penelitian bertujuan untuk menambah informasi ilmiah penelitian. Apabila penelitian tidak dilakukan dengan benar kesimpulan yang akan didapat pun 
akan menjadi rancu dan tidak kuesioner terhadap responden memperolehkan hasil yang di pengunjung dan masyarakat yang harapkan.

beraktivitas ekonomi di Taman

Sutrisno Hadi dalam Arikunto Muko-Muko.

(2006) mendefenisikan variabel

Penyusunan menentukan sebagai gejala yang bervariasi, instrumen yang berbentuk angket sedangkan yang di maksud dengan dialakukan melalui menentukan gejala di sini Obyek penelitian, indikator variabel. Langkah-langkah sehingga variabel adalah obyek yang dilakukan dalam pembuatan penelitian yang bervariasi. Instrumen angket ini adalah dengan menentukan pengumpulan data adalah alat bantu indikator-indikator variabel yag yang dipilih dan digunakan oleh disesuaikan dengan pertanyaan yang peneliti dalam kegiatan akan diangkat, kemudian masingmengumpulkan data agar kegiatan masing indikator di jabar lagi menjadi tersebut menjadi sistematis dan butir-butir pertanyan. Adapun dipermudah olehnya (Arikunto, pembagian dari masing-masing 2010). Instrumen pengumpulan data indikator dapat dilihat pada Tabel.2 yang digunkan dalam penelitian ini berikut yaitu: adalah observasi dengan menggunkan 
Tabel 2. Kisi-kisi Instrumen Penelitian

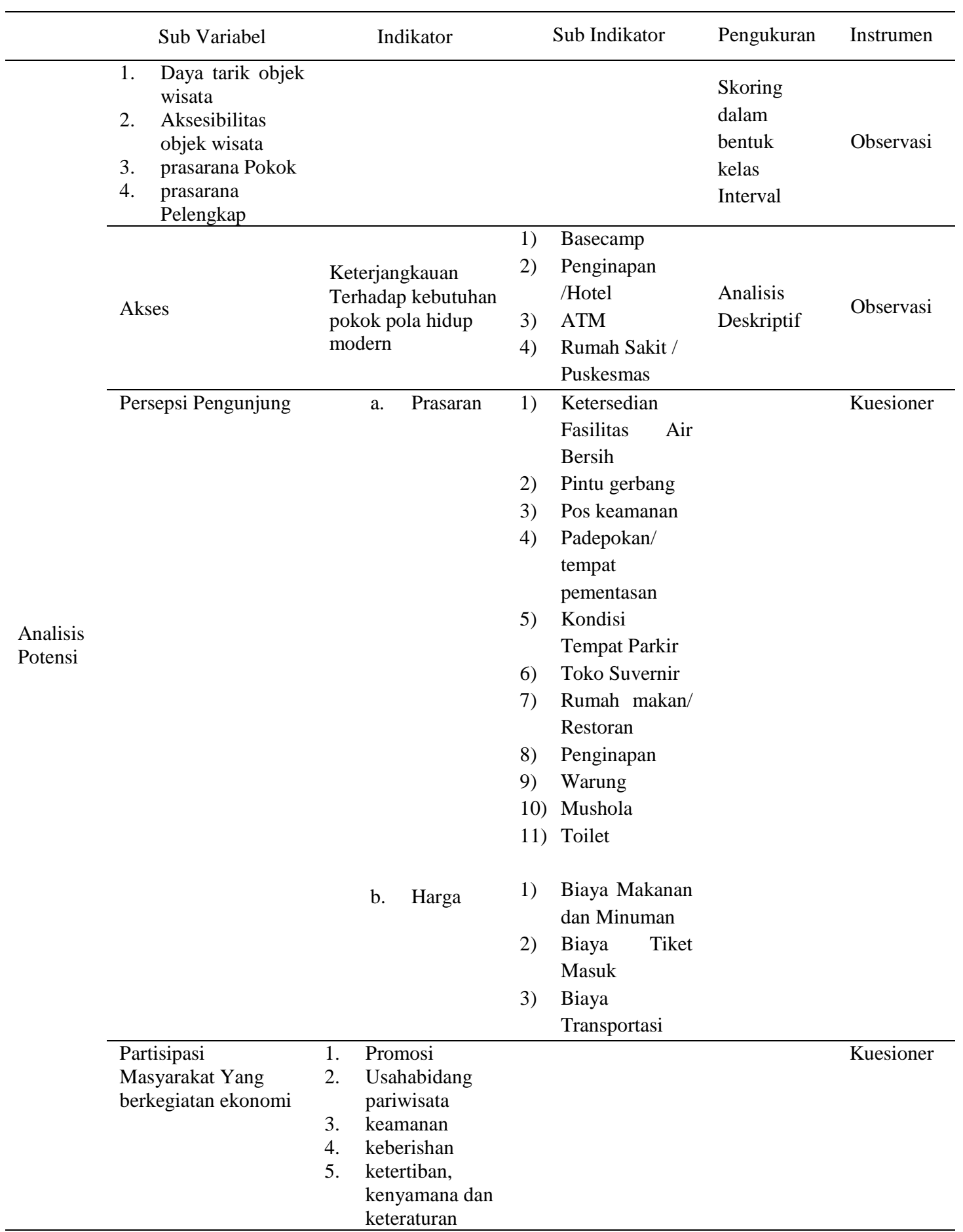

Sumber: Pengolahan Data Primer, 2018 
Menurut Sugiyono (2009) analisis data adalah proses mencari dan menyusun serta secara sistematis data yang di peroleh dari hasil wawancara, catatan lapangan, dan dokumentasi dengan cara mengorganisasikan data kedalam kategori, menjabarkan kedalam pola, memilih mana yang penting dan yang akan di pelajari, dan membuat kesimpulan sehingga mudah dipahami oleh diri sendiri dan orang lain.

Pemilihan indikator penelitian ini diperoleh dari penelitian sejenis, kemudia dimodifikasi dan di sesuaikan dengan kondisi kepariwisataan objek wisata Taman Muko-Muko melalui pendekatan secara geografi.

Untuk menganalisis potensi obyek wisata Taman Muko-Muko, penulis menggunakan teknik pengharkatan, teknik ini di gunakan untuk memberikan nilai pada masingmasing karakteristik parameter dari indikator-indikator agar dapat di hitung nilainya serta data di tentukan peringkatnya.

Model pengharkatan (Scoring Model) yang diacu dari modl penelitian Cappock (1971) dan Gunn (1979), (dalam Pramudia E, 2008:26). Metode ini mengkuantitatifkan kenampakan setiap objek wisata seperti jaringan jalan dalam bentuk jarak objek dari pusat pelayanan, prasarana prasarana penunjang (Hotel/Penginapan, Rumah makan, Bank/ATM, pasar, Rumah Sakit/ Puskesmas, terminal), jenis atau daya tarik objek wisata, ada tidaknya pengelola wisata, frekuensi pengadaan antraksi wisata obejek penelitian, ada tidaknya petugas keamanan dan jumlah penjualan cinderamata dan makanan/minuman yang ada di objek penelitian. Sehingga dapat dilihat objek yang mempunyai potensi untuk di kembangkan melalui akumulasi skor atau penilaian.

Peringkat masing-masing indikator diurutkan menjadi beberapa kategori, mulai nilai harkat tertinggi yang bernilai 5 hingga harkat terendah yang bernilai 1, pengharkatan tersebut akan menentukan bagaimana Potensi di Obyek Wisata Taman Muko-Muko.

Kriteria pengharkatan dan pembobotan di peroleh melalui modifikasi dengan menyesuaikan kondisi daerah penelitian, model Gunn, 1979 dan Cappock, 1971 (dalam Pramudia E, 2008).

Dalam penelitian ini, untuk mengetahui potensi objek wisata Taman Muko-Muko digunakan teknik analisis skoring dan klasifikasi, selanjutnya untuk mengetahui usaha pengembangan objek wisata Taman Muko-Muko digunakan teknik analisis TOWS (Threats, Opportunities, Weaknesses \& Strengths).

\section{HASIL DAN PEMBAHASAN}

Gambaran data hasil penelitian dapat digunakan untuk memperkaya pembahasan, melalui gambaran data tanggapan reponden dapat diketahu bagaiman tanggapan responden terhadap setiap variabel yang di teliti. 
Agar lebih mudah menginterprestasikan variabel yang sedang di teliti, dilakukan analisis persentase respon pengunjung yang di lanjutkan dengan teknik pengharkatan (scoring model) dengan menggunakan tabel untuk menjelaskan bagaimana gambaran tanggapan responden mengenai variabel tanggapan pengunjung dan masyarakat yang berkegiatan ekonomi. Prinsip kategorisasi jumlah skor tanggapan responden di adopsi dari Arikunto (2008). Dari jawaban responden, kemudian disusun kriteria penilaian untuk setiap item pertanyaan berdasarkan persentase dengan langkah-langkah sebagai berikut: 1) Nilai kumulatif adalah nilai dari setiap pertanyaan yang merupakan jawaban dari setiap responden. 2) Penentuan nilai potensi dari observasi peneliti suatu obyek wisata dilakukan dengan mengalihkan nilai masing-masing indikator dengan bobot suatu klasifikasi. Setelah didapatkan hasil dari operasi diatas, Hasil Skor pencapaian total skor terhadap skor ideal dipetakan ke dalam interval kriteria penilaian terhadap di atas yang di sajikan melalui sebuah tabel kontinum. 3) Jumlah responden untuk persepsi pengunjung adalah 30 orang dan partisipasi pengunjung 10 responden, dan nilai skala pengukuran . Deskripsi data dan hasil penelitian akan di jelaskan sebagai berikut:

Penilaian variabel penelitian objek wisata Taman Muko-Muko di Kecamatan Tanjung Raya, Kabupaten
Agam metode skoring ini digunakan empat variabel, yaitu daya tarik objek wisata, aksesibilitas objek wisata, variabel prasarana pokok kegiatan wisata dan prasarana pelengkap kegiatan wisata.

Setiap variabel penelitian ini diberi bobot rentang $1-4$ untuk menilai tingkat tinggi rendahnya nilai sebuah objek wisata. Nilai skoring ditentukan untuk membedakan pengaruh antara beberapa kriteria dalam suatu variabel penelitian. Hasil penilaian variabel penelitian objek adalah sebagai berikut:

Salah satu daya tarik objek wisata Taman Muko-Muko adalah kawasan tepi ujung Maninjau yang berbentuk melengkung dan berada di lokasi terowong Pembangkit Listrik Tenaga Air, Lokasi Pembangkit Listrik Tenaga Air (PLTA) Maninjau, di dukung dengan dermaga dan jebatan pancing berada langsung di tepi danau menjadikan Taman Muko-Muko wisata air untuk pengembangnya tentu saja kegiatan wisata air ini akan berpotensi lebih besar kedepannya.

Potensi dari obyek wisata dari hasil penilaian yang dilakukan berdasarkan daya tarik terhadap masing-masing parameter yang di tetapkan dari hasil modifikasi penelitiaan yaitu memperoleh skor 144 maka disimpulkan bahwa Karakteristik Daya Tarik objek wisata Taman MukoMuko yang menjadi faktor pendorong dan faktor penghambat adalah seimbang atau sama. 
Aksesibilitas dalam pariwisata faktor penting untuk meningkatkan minat wisatawan, aksesibilitas buruk, akan mempersulit wisatawan untuk berkunjung ke Taman Muko-Muko. Penilaian aksesibilitas di Taman Muko-Muko, maka peneliti menggunakan 3 (tiga) indikator yaitu jarak Taman Muko-Muko dari jalan raya, kualitas jalan dan ketersediaan angkutan umum menuju objek wisata. Untuk melihat jaringan jalan di Kecamatan Tanjung Raya, variabel aksesibilitas objek wisata ini diberi bobot angka 3. Penilaian variabel aksesibilitas objek wisata potensi dari obyek wisata dari hasil penilaian yang dilakukan berdasarkan aksesibilitas objek wisata terhadap masing-masing parameter yang di tetapkan dari hasil modifikasi penelitiaan yaitu memperoleh skor 81 maka disimpulkan bahwa Sebagian besar karakteristik aksesibilitas objek wisata Taman Muko-Muko merupakan faktor utama untuk berkembang.

Dalam penelitian ini ada 4 (empat) prasarana pokok yang dinilai, yaitu tempat warung, MCK, tempat ibadah/mushola, dan Parkir. Prasarana pokok memiliki pengaruh lebih kecil terhadap kunjungan wisatawan dibanding faktor daya tarik dan aksesibilitas, maka dari itu variabel prasarana pokok ini diberi bobot angka lebih rendah yaitu 2 (dua). Penilaian variabel prasarana pokok kegiatan wisata

Potensi dari obyek wisata dari hasil penilaian yang dilakukan berdasarkan potensi prasarana pokok kegiatan wisata terhadap masingmasing parameter yang di tetapkan dari hasil modifikasi penelitiaan yaitu memperoleh skor 36 maka disimpulkan bahwa Sebagian besar karakteristik prasarana pokok kegiatan wisata pada objek wisata Taman Muko-Muko merupakan faktor pendorong pengembangan objek wisata.

Prasarana pelengkap aktivitas wisata juga berperan dalam kegiatan wisata di Taman Muko-Muko yaitu memberi kemudahan bagi wisatawan yang berkunjung. Prasarana pelengkap kegiatan wisata diberi bobot nilai terendah yaitu 1 (satu), karena kurang mempengaruhi wisatawan untuk berkunjung.

Potensi dari obyek wisata dari hasil penilaian yang dilakukan berdasarkan potensi prasarana pelengkap kegiatan wisata terhadap masing-masing parameter yang di tetapkan dari hasil modifikasi penelitiaan yaitu memperoleh skor 10 maka disimpulkan bahwa Karakteristik Prasarana Pelengkap Kegiatan Wisata pada objek wisata Taman Muko-Muko yang menjadi faktor pendorong dan faktor penghambat adalah seimbang atau sama.

Tujuan dari analisis untuk mengetahui keadaan prasarana di objek wisata Taman Muko-Muko berada di wilayah Kabupaten Kabupaten Agam agar memudahkan dalam mengarahkan pengembangan untuk perencanaan pembangunan prasaran di objek wisata Taman Muko-Muko ini kedepannya. 


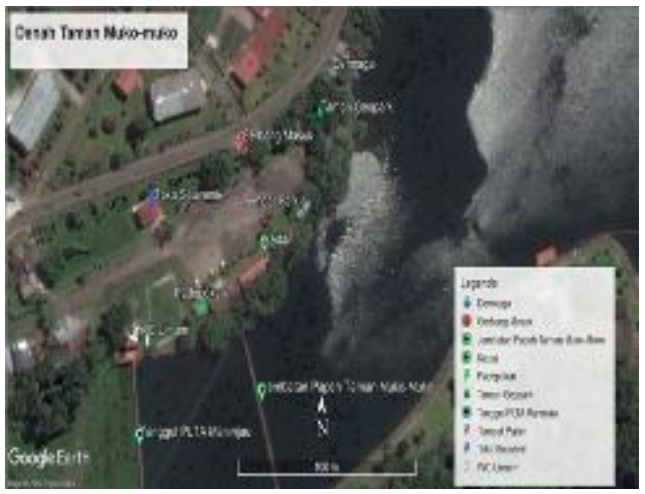

Gambar 1. Denah Taman Muko-Muko

Sumber: Google Earth, 2018

Aksesibilitas adalah tingkat kemudahan untuk menjangkau suatu tujuan/suatu tempat. Dalam objek tujuan wisata Taman Muko-Muko Kabupaten Agam, jaringan jalan merupakan hal yang sangat penting. Tujuan dari analisis ini adalah untuk mengetahui jarak menuju akomondasi dari Taman Muko-Muko Kabupaten Agam untuk memberikan Informasi kepada wisatawan menjadi lebih mudah mengunjungi ke lokasi objek wisata karena aksesibilitas merupakan hal yang penting dalam ketepatan, kecepatan dan kelancaran (Pendit, 1999).

Tujuan dari analisis ini adalah untuk mengetahui keadaan infrastruktur di objek wisata Taman Muko-Muko yang berada di wilayah Kabupaten Kabupaten Agam agar memudahkan dalam mengarahkan pengembangan karena infrastruktur merupakan fasilitas pendukung dalam kegiatan pariwisata pada masa yang akan datang, dengan terlayani fasilitas akomondasi wisata Sarana dan prasarananya (Penginapan, rumah makan, keberadaan bank/ATM, pasar, terminal dan rumah sakit/puskesmas) wisatawan akan mendapatkan kenyamanan selama berada di lokasi objek wisata.

Basecamp menurut kamus bahasa indonesia adalah Barak Pangkalan maksudnya disini tempat dimana wisatawan mempersiapan untuk kegiatan wisatawan. Basecamp penelitian di ambil dari 2 kota yaitu Kota Padang dan Kota Bukittinggi sebagai basecamp wisatawan menuju objek wisata Taman Muko-Muko.

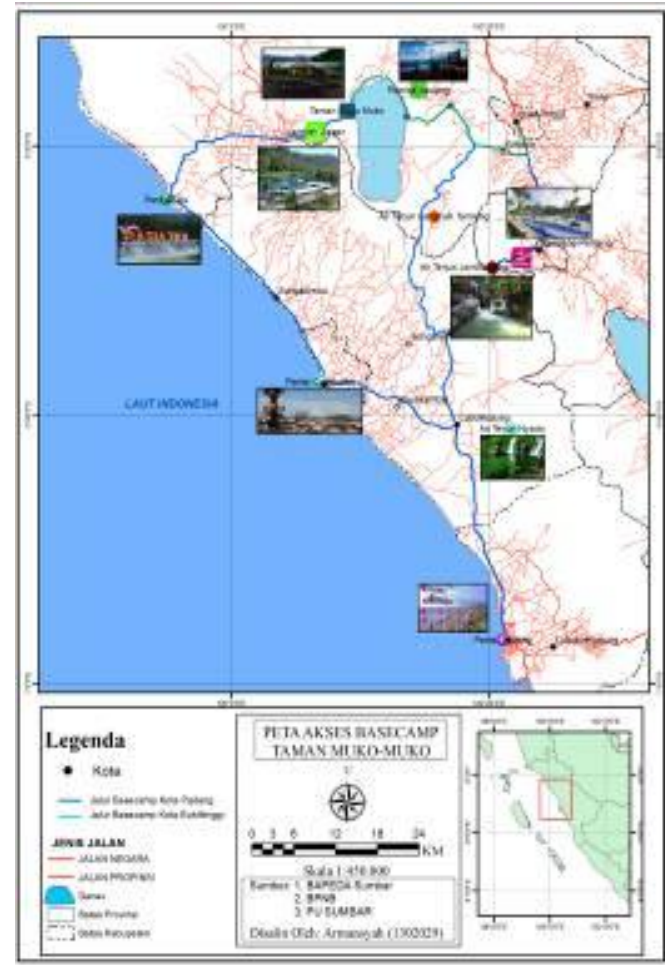

Gambar 2. Peta Basecamp wisata Taman MukoMuko

Sumber: BAPPEDA Sumbar, BNPB, dan Peta Adm. Kab. Agam 2017

Setelah hasil penilaian variabel penelitian dan klasifikasi potensi objek wisata Taman MukoMuko diketahui, maka selanjutnya dapat dilakukan analisis usaha pengembangan objek wisata Taman Muko-Muko. Dari hasil penilaian 
variabel penelitian yangtelah dilakukan dapat diketahui potensi apa saja yang menjadi faktor pendorong dan penghambat dalam pengembangan objek wisata Taman Muko-Muko. Dalam penelitian ini, usaha pengembangan objek wisata Taman Muko-Muko dilakukan dengan menggunakan metode analisis TOWS
(Threats, Opportunities, Weaknesses \& Strengths) yaitu menganalisis berdasarkan aspek ancaman, peluang, kelemahan dan kekuatan yang terdapat pada objek wisata Taman Muko-Muko. Berdasarkan analisis TOWS, objek wisata Taman Muko-Muko mempunyai:

\section{Tabel 3. Usaha Pengembangan Objek Wisata Taman Muko-Muko}

\begin{tabular}{|c|c|c|c|}
\hline No & $\begin{array}{c}\text { Aspek } \\
\text { Pengembangan }\end{array}$ & $\begin{array}{c}\text { Kondisi PadaWaktu } \\
\text { Penelitian }\end{array}$ & Usaha Pengembangan \\
\hline 1 & $\begin{array}{l}\text { Daya tarik objek } \\
\text { wisata }\end{array}$ & $\begin{array}{l}\text { Objek wisata } \\
\text { Muko-Muko mempunyai } \\
\text { nilai unik lokal pada } \\
\text { Kecamatan } \\
\text { Kabupaten Agama dengan } \\
\text { objek wisata taman Muko- } \\
\text { Muko di Kematan Tanjung } \\
\text { Raya yaitu objek wisata } \\
\text { rekreasi. }\end{array}$ & $\begin{array}{l}\text { Penambahan atraksi objek wisata } \\
\text { seperti pertunjukan musik atau acara } \\
\text { budaya lokal agar nilai keunikannya } \\
\text { berbeda dari objek wisata rekreasi } \\
\text { lainnya, untuk meningkatkan minat } \\
\text { wisatawan untuk berkunjung objek } \\
\text { wisata Taman Muko-Muko. }\end{array}$ \\
\hline 2 & Aksesibilitas & $\begin{array}{l}\text { Kurangnya rambu-rambu } \\
\text { penunjuk jalan pada objek } \\
\text { wisata Taman Muko-Muko, } \\
\text { khususnya di sepanjang Jl. } \\
\text { Maninjau- lubuk basung. }\end{array}$ & $\begin{array}{l}\text { Penambahan rambu-rambu penunjuk } \\
\text { jalan menuju objek wisata Taman } \\
\text { Muko-Muko, khususnya di sepanjang } \\
\text { Jl. Lubuk Basung- Bukittinggi }\end{array}$ \\
\hline 3 & $\begin{array}{l}\text { Prasarana pokok } \\
\text { kegiatan } \\
\text { penelitian }\end{array}$ & $\begin{array}{l}\text { Prasarana pokok } \\
\text { wisata segiatan } \\
\text { ibadah } \\
\text { pengelolaannya kurang baik, } \\
\text { sehingga pengujung kurang } \\
\text { merasa nyaman. }\end{array}$ & $\begin{array}{l}\text { Perbaikan prasarana tempat ibadah / } \\
\text { mushola supaya wisatawan merasa } \\
\text { nyaman dalam melaksanakan kewajiban } \\
\text { ibadahnya ketika berkunjung ke objek } \\
\text { wisata Taman Muko-Muko }\end{array}$ \\
\hline 4 & $\begin{array}{l}\text { Prasarana } \\
\text { pelengkap } \\
\text { kegiatan wisata }\end{array}$ & $\begin{array}{l}\text { Tidak tersedia Prasarana } \\
\text { penginapan / akomodasi di } \\
\text { objek wisata taman Muko- } \\
\text { Muko. }\end{array}$ & $\begin{array}{l}\text { Penyediaan prasarana pelengkap } \\
\text { kegiatan wisata, yaitu prasarana } \\
\text { penginapan/ akomodasi di sekitar objek } \\
\text { wisata tidak harus menempuh lebih dari } \\
\text { radius } 10 \mathrm{~km} \text { menuju penginapan. }\end{array}$ \\
\hline 5 & $\begin{array}{l}\text { Penataan } \\
\text { ruangan }\end{array}$ & $\begin{array}{l}\text { Pedagang yang berjualan } \\
\text { pada tempat-tempat yang } \\
\text { tidak semestinya } \\
\text { mengganggu pejalan di } \\
\text { objek wisata. }\end{array}$ & $\begin{array}{l}\text { pengaturan tempat bagi para pedagang } \\
\text { supaya wisatawan tidak terganggu dan } \\
\text { nyaman dalam melakukan kegiatan } \\
\text { wisatanya serta tidak mengurangi } \\
\text { keindahan objek wisata }\end{array}$ \\
\hline 6 & $\begin{array}{l}\text { Produk } \\
\text { unggulan }\end{array}$ & $\begin{array}{l}\text { Belum beragam produk } \\
\text { cinderamata yang khas pada } \\
\text { objek wisata Taman Muko- } \\
\text { Muko }\end{array}$ & $\begin{array}{l}\text { Menambah kreasi produk cinderamata } \\
\text { khas dengan kualitas sehingga } \\
\text { meningkatkan kunjungan wisatawan } \\
\text { pada objek wisata Taman Muko-Muko } \\
\text { sebagai kenang-kenangan wisatawan } \\
\text { ketika pulang berkunjung. }\end{array}$ \\
\hline
\end{tabular}

Sumber: Pengolahan Data Primer, 2018 


\section{PENUTUP}

Berdasarkan simpulan di atas, maka diharapkan kepada Pemerintah untuk tetap bekerja sama dengan pihak pengelola obyek wisata guna menjaga agar potensi yang sudah ada tidak berkurang ataupun rusak.

Masyarakat sekitar juga turut menjaga potensi yang ada di sekitar obyek wisata maupun di obyek wisata lain yang ada di Kabupaten Agam karena keberadaannya tersebut secara tidak langsung juga membantu masyarakat mencari rezeki maupun pekerjaan.

Menjaga potensi yang ada memang sulit itu dikarenakan karakter tiap orang berbeda-beda, oleh sebab itu seluruh pihak yang bersangkutan untuk dapat bekerja sama menjaga potensi yang ada tersebut.

Diharapkan bagi masyarakat dan seluruh segenap yang ikut andil dalam menjaga fasilitas yang ada pada objek wisata. Untuk pengembangan potensi maka di perlukan penambahan fasilitas yang kurang untuk menunjang pertumbuhan pengunjung di objek wisata Taman Muko-Muko di Kabupaten Agam.

\section{DAFTAR PUSTAKA}

Arikunto, Suharsimi. 2010. Prosedur Penelitian Suatu Pendekatan Praktek. Jakarta: Rineka Cipta

Arikunto, Suharsimi. 2008. Prosedur Penelitian Suatu Pendekatan Praktek. Jakarta: Rineka Cipta
Arikunto, Suharsimi. 2006. Prosedur Penelitian Kualitatif. Jakarta: Rineka Cipta

Bakaruddin. 2009. Perkembangan dan Permasalahan Kepariwisataan. UNP Press: Padang

Dinas Pariwisata Kabupaten Agam, 2015. Pariwisata Kabupaten Agama buletin 2015. Lubuk Basung: Dinas Pariwisata dan Olahraga Kabupaten Agam

Pendit, Nyoman N. 1999. Ilmu Pariwisata Sebuah pengantar Perdana. Jakarta: Pradiya Paramita

Pramudia, E. 2008. Evaluasi Potensi Obyek Wisata Aktual di Kabupaten Agam Sumatera Barat Untuk Perencanaan Program Pengembangan. Tesis Tidak di Terbitkan: epository.ipb.ac.id

Sudjana, N. 2004. Dasar-dasar Proses Belajar Mengajar. Bandung: Sinar

Sugiyono. 2011. Metode Penelitian Bisnis (Pendekatana Kuantitatif, Kualitatif, dan $R \& B$ ). Bandung : Alfabeta

Sugiyono. 2009. Metode Penelitian Bisnis (Pendekatana Kuantitatif, Kualitatif, dan $R \& B$ ). Bandung : Alfabeta

Suwantoro, Gamal. 2004. Dasar-dasar Pariwisata. Yogyakarta: Andi

Tika, P. 2005. Metode Penelitian Geografi. Jakarta: Bumi Aksara 